\title{
Consumers' Purchase Intention: Influencing Factors Unveiled at Korean Thematic Café (Case Study: Chingu Café)
}

\author{
HARIMUKTI WANDEBORI, VINON WIJAYA \\ School of Business and Management ITB, Bandung 40132, Indonesia \\ Email correspondence: harimukti@sbm-itb.ac.id
}

\begin{abstract}
Service quality, atmosphere, and food quality have become an important part to be considered by a firm or company in order to attract consumers and to compete in the marketplace. This research will be taking Chingu Café which is located in Bandung, Indonesia to be the object of study. This research applied a quantitative method with a total sample of 384 respondents who have been to Chingu Café. A multi linear regression was applied to analyze the findings in order to gain the effect of service quality's dimensions, food quality, and atmosphere on purchase intention. This research is able to gather unique findings in a Korean thematic café business. It is obtained that the most consumptive consumers are teenagers and young adults dominated by females. More importantly, this research is able to learn that service quality (tangible, reliability, responsiveness, and empathy), atmosphere, and food quality have a positive influence on purchase intention while none of such relationship between assurance dimension and purchase intention.
\end{abstract}

Key words: Purchase intention, Service quality

\section{Niat Pembelian Konsumen: Faktor-faktor yang Mempengaruhi di Kafe Tematik Korea (Studi Kasus: Chingu Café)}

\begin{abstract}
Abstrak
Kualitas layanan, suasana dan kualitas makanan telah menjadi bagian yang penting untuk dipertimbangkan oleh organisasi atau perusahaan untuk menarik perhatian konsumen dan dapat berkompetisi dalam lingkungan industri. Penelitian ini berlokasi di Chingu Café yang berada di Bandung, yang juga merupakan obyek studi. Metode penelitian kuantitatif dilakukan dengan jumlah sampel sebesar 384 orang dari mereka yang pernah berkunjung ke Café ini. Selanjutnya, regresi multi linear digunakan untuk mengungkapkan pengaruh dan akibat dari dimensi-dimensi kualitas layanan, kualitas makanan dan suasana terhadap minat beli. Penelitian ini memberikan informasi mengenai temuan yang unik dalam bisnis café bertema Korea di Indonesia. Didapatkan bahwa konsumen yang paling banyak melakukan konsumsi adalah anak remaja dan dewasa muda yang didominasi oleh wanita. Selebihnya, penelitian ini mengungkap bahwa kualitas layanan (fasilitas terlihat, keandalan, kemampuan reaksi dan empati), suasana dan kualitas makanan memiliki pengaruh yang positif terhadap minat beli. Sebaliknya, tidak ada hubungan antara dimensi jaminan dengan minat beli.
\end{abstract}

Kata kunci: Niat Pembelian, Kulitas Pelayanan. 


\section{INTRODUCTION}

Purchase intention is referred to how consumers would likely to make a transaction by considering service quality, atmospheric environment, and food quality. Moreover, recent studies (Pi, Liao, Liu, \& Lee, 2011; Pavlou \& Geven, 2004) have proved consumers' actual buying behavior as well as their probability in creating another transaction in the future are reflected by purchase intention.

Service quality is globally defined as a superiority of service provided by a firm or company where it has been suggested in order to make a competitive advantage in the marketplace (Parasuraman, Zeithaml, \& Berry 1988). It is seen as an interactive process of creating value to be delivered to consumers (Fitzsimmons \& Fitzaimmons, 2008). Service quality has been an important key for a firm or company to gain its loyal consumers and to avoid consumers preferring other competitors that can meet their expectation and create satisfaction.

Wakefield and Baker (1998) have proved that the probability of consumers feeling satisfied and staying longer in a store increases due to the result of the service quality and the store's atmosphere provided by the firm or company. It means that store's service quality and atmosphere has a high impact on consumers' satisfaction which is also able to increase their purchase intention while staying in the store. Besides service quality and atmosphere, food quality also plays an important role in achieving consumers' satisfaction and increase purchase intention.

For Korean thematic cafés in Indonesia, they have endeavored to gain loyal consumers. Many issues applied in implementing a Korean atmosphere into a business such as a café. In this research, Chingu Café was the object to be studied. Chingu Café was a Korean thematic café located on Jl. Sawunggaling No. 10 Dago, Bandung, opened daily starting from 10.00 - 22.00. The café was established in 2013, aiming to pamper its consumers with delightful Korean cuisines and modern Korean atmosphere to make its consumers feel like being in Korea. The name of Chingu itself was adopted from a Korean term which means 'friend'. It was chosen because the term Chingu matches with the theme of Chingu Café of friendly atmosphere that can be seen and felt by every consumer visiting the café. Chingu Café always greet its consumers warmly in Korean to make sure its consumers feel happy and satisfied.

Currently, Chingu Café started to gain its popularity in Bandung. The café was known for its Korean thematic café, Korean cuisines, and atmospheres with the dominant consumers of female teenagers. Despite the fact, Chingu Café required an assessment to understand the consumers' expectation regarding the café in fulfilling their satisfaction, and which section required improvements, to nail its legacy by sustainably attracts and appeals consumers' interest to exercise the purchase intention.

\section{LITERATURE REVIEW}

The theoretical framework of this research was developed by studying previous research as depicted in Table 1. In summary, it was revealed that service quality, atmosphere, and food quality to have an influence or linear relationship on purchase intention. Based on the preceding theoretical review, a theoretical framework, as presented in Figure 1, was

Table 1. Previous research

\begin{tabular}{|c|c|c|c|}
\hline Researcher & Objectives & Variable & Findings \\
\hline $\begin{array}{l}\text { Perez, Abad, Carrillo, and Fernandez } \\
\text { (2007). }\end{array}$ & $\begin{array}{l}\text { To investigate the relationship } \\
\text { between service quality and } \\
\text { behavioral purchase intentions in the } \\
\text { public-sector transport industry in } \\
\text { Spain. }\end{array}$ & $\begin{array}{l}\text { - Tangible } \\
\text { - Reliability } \\
\text { - Receptivity } \\
\text { - Assurance } \\
\text { - Empathy } \\
\text { - Behavioral purchase intention }\end{array}$ & $\begin{array}{l}\text { All service quality's dimensions have a } \\
\text { relationship with behavioral purchase } \\
\text { intention. }\end{array}$ \\
\hline
\end{tabular}


Continue of Table 1. Previous research

\begin{tabular}{|c|c|c|c|}
\hline Researcher & Objectives & Variable & Findings \\
\hline $\begin{array}{l}\text { Parasuraman, Zeithaml, and Berry } \\
\text { (1988). }\end{array}$ & $\begin{array}{l}\text { To confirm the multiple-item instruments } \\
\text { for assessing service quality. }\end{array}$ & $\begin{array}{l}\text { - Tangible } \\
\text { - Reliability } \\
\text { - Responsiveness } \\
\text { - Communication } \\
\text { - Credibility } \\
\text { - Security } \\
\text { - Competence } \\
\text { - Courtesy } \\
\text { - Customer knowledge } \\
\text { - Access } \\
\text { - Service quality }\end{array}$ & $\begin{array}{l}\text { It is obtained that tangible, reliability, } \\
\text { responsiveness, assurance, and } \\
\text { empathy are able to be applied } \\
\text { in assessing service quality with a } \\
\text { total of } 22 \text {-items where the other } \\
\text { dimensions are included in assurance } \\
\text { and empathy. }\end{array}$ \\
\hline Hassan, Hashimi, and Sarwar (2014). & $\begin{array}{l}\text { To investigate the effect of service quality } \\
\text { on purchase intention with CSR as the } \\
\text { moderating role. }\end{array}$ & $\begin{array}{l}\text { - Service quality } \\
\text { - CSR } \\
\text { - Purchase intention }\end{array}$ & $\begin{array}{l}\text { Service quality has a positive } \\
\text { relationship with purchase intention } \\
\text { and CSR moderates between service } \\
\text { quality and purchase intention. }\end{array}$ \\
\hline Hussain and Ali (2015). & $\begin{array}{l}\text { To investigate the effects of atmosphere } \\
\text { on the consumer purchase intention in } \\
\text { international retail chain outlets of Karachi, } \\
\text { Pakistan. }\end{array}$ & $\begin{array}{l}\text { - Cleanliness } \\
\text { - Music } \\
\text { - Scent } \\
\text { - Temperature } \\
\text { - Lighting } \\
\text { - Color } \\
\text { - Display/layout } \\
\text { - Purchase intention }\end{array}$ & $\begin{array}{l}\text { - Significant: } \\
\text { ? Cleanliness } \\
\text { ? Scent } \\
\text { ? Lighting } \\
\text { ? Display/layout } \\
\text { - Insignificant: } \\
\text { ? Music } \\
\text { ? Temperature }\end{array}$ \\
\hline $\begin{array}{l}\text { Worek, Kindangen, and Worang } \\
\text { (2015) }\end{array}$ & $\begin{array}{l}\text { To investigate the effect of atmosphere } \\
\text { and service quality on purchase intention } \\
\text { simultaneously, effect of restaurant and } \\
\text { service quality partially, and service quality } \\
\text { on purchase intention partially. }\end{array}$ & $\begin{array}{l}\text { - Atmosphere } \\
\text { - Service quality } \\
\text { - Purchase intention }\end{array}$ & \\
\hline Ryu, Lee, and Woo (2012) & $\begin{array}{l}\text { To investigate the relationship between } \\
\text { predictors which are food quality, service } \\
\text { quality, and physical environment quality, } \\
\text { moderator which is perceived price } \\
\text { (moderator), and criterions which are } \\
\text { satisfaction and behavioral intention.. }\end{array}$ & $\begin{array}{l}\text { - Food quality } \\
\text { - Service quality } \\
\text { - Physical environment quality } \\
\text { - Perceived price } \\
\text { - Customer satisfaction } \\
\text { - Behavioral intention }\end{array}$ & $\begin{array}{l}\text { - Significant: } \\
\text { ?? Food quality } \\
\text { ? Physical environment } \\
\text { ? Customer satisfaction } \\
\text { ? Perceived price }\end{array}$ \\
\hline Qin and Prybutok (2009) & $\begin{array}{l}\text { To investigate the relationship between } \\
\text { service quality, food quality, perceived } \\
\text { value, customer satisfaction, and behavioral } \\
\text { intentions in fast-food restaurants }\end{array}$ & $\begin{array}{l}\text { - Service quality } \\
\text { - Food quality } \\
\text { - Perceived value } \\
\text { - Customer satisfaction } \\
\text { - Behavioral intention }\end{array}$ & \\
\hline
\end{tabular}

able to be constructed revealing all independent variables (service quality composing of empathy, assurance, responsiveness, reliability, and tangible; atmosphere, and food quality) to possess linear relationships with the dependent variable (purchase intention).

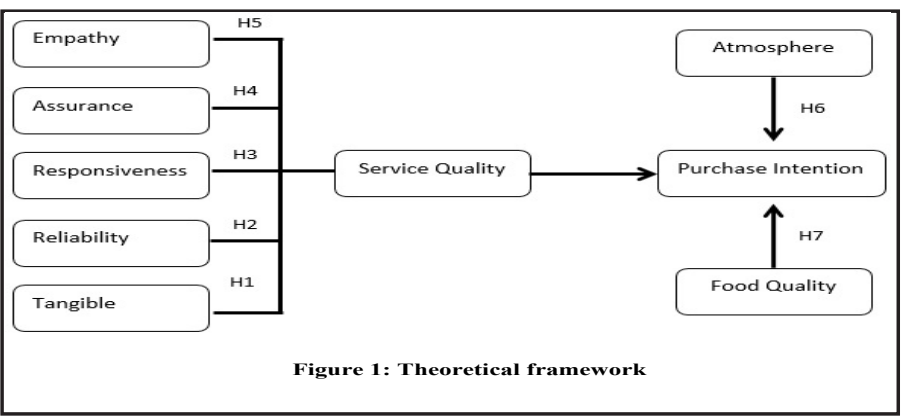

\section{Purchase intention}

Purchase intention is the willingness of consumers' to make a transaction with a retailer. It reflects as a promise to one's self to re-purchase a product on one's next trip (Fandos \& Flavian, 2006; Halim and Hameed, 2005).

\section{Service quality}

Service quality defines the assessment of how well a service meets with consumers' expectation (Zeithaml, Bitner, \& Gramler, 2006). This assessment is able to be used to assess the quality of services provided by a firm or company in order to identify problem faced by a firm or company which is started from analysis and measurement (Edvardsen, 1994). 
The SERVQUAL model applied in this research was developed by Parasuraman, Zeithaml, \& Berry (1988) which are tangible, reliability, responsiveness, assurance, and empathy in order to gain the influence of service quality's dimensions on purchase intention. This model is able to be applied repeatedly on a regular basis as the benchmark of service quality. It is able to be implemented annually in order to gain repeat yearly comparisons, to determine how the improvement of service quality has influenced on consumers' perceptions and the effectiveness or service quality provided to consumers (Shahin, 2006).

\section{Tangible}

Represents service physically including physical facilities, location, equipment used, and the appearance of employees. Service quality is also evaluated by consumers, especially new consumers through examining the physical representation or atmospheric environment of tangible dimension provided by a company or firm. It is also referred to the presentation of store's physical layout and the convenience offered to consumers (Subhash, Ashok, \& Soon, 2000).

$\mathrm{H} 1$ : Tangible dimension has a positive influence on purchase intention

\section{Reliability}

Represents the ability to deliver service to meet consumers' expectation including punctuality, equal service given to every consumer, sympathetic attitude, and high accuracy. Reliability is also related to the ability of a company or firm to deliver its promises such as delivery, service provision, problem resolution, and pricing to it consumers.

$\mathrm{H} 2$ : Reliability dimension has a positive influence on purchase intention.

\section{Responsiveness}

Responsiveness represents the ability to deliver a responsive service to give information to consumers including paying attention to consumers' requests, questions, and closeness. Responsiveness determines about how a company or firm help its consumers in responding their needs and questions. Responsiveness is measured by the length of time spent by consumers to wait for assistances.

H3: Responsiveness dimension has a positive influence on purchase intention.

\section{Assurance}

Assurance represents the ability to create trust into consumers including knowledge and courtesy of employees to inspire trust and confidence. Assurance is considered important for a company or firm in order to evaluate outcomes of consumers which are perceived to be high risk. Trust and confidence are related to the person who will make a contact with consumers in order to create a positive relationship between company or firm with consumers.

$\mathrm{H} 4$ : Assurance dimension has a positive influence on purchase intention.

\section{Empathy}

Empathy represents for caring and individual attention a firm or company provides to its consumers including acknowledging the consumers, understand their needs and provides a comfortable operational time for consumers in order to make consumers feel unique and special. In this dimension, consumers would likely to be understood personally to create a warm feeling in them.

H5: Empathy dimension has a positive influence on purchase intention.

\section{Food quality}

The quality of food is important for a business that offers a dining experience to maintain a high quality of cuisines in order to satisfy the needs and expectation of its consumers. In a café or restaurant industry, consumers' satisfaction with food quality is related to purchase intention where there is a probability of consumers to make a repeat purchase (Cho \& Park, 2001).

Qin and Prybutok (2009) studied about the relationship between service quality, food quality, perceived value, customer satisfaction, and behavioral intention in fast-food restaurants and has stated that food quality has a positive and direct influence on consumer's satisfaction. In this research, the attributes of food quality implemented were the freshness of food, the taste of food, nutrition of food, the variety of menu, and the smell of food (Ryu, Lee, Kim, \& Woo 2012). H6: Food quality has a positive influence on purchase intention.

\section{Atmosphere}

Previous research (Worek, Kindangen, \& Worang, 
Table 4. $\mathrm{t}$ Test analysis

Coefficients $^{a}$

\begin{tabular}{|c|c|c|c|c|c|c|c|}
\hline \multirow[b]{2}{*}{ Mod } & & \multicolumn{2}{|c|}{$\begin{array}{c}\text { Unstandardized } \\
\text { Coefficients }\end{array}$} & \multirow{2}{*}{$\begin{array}{c}\begin{array}{c}\text { Standardized } \\
\text { Coefficients }\end{array} \\
\text { Beta }\end{array}$} & \multirow[b]{2}{*}{$\mathrm{t}$} & \multirow[b]{2}{*}{ Sig. } & \multirow{2}{*}{$\begin{array}{c}\begin{array}{c}\text { Correlatio } \\
\text { ns }\end{array} \\
\text { Zero-order }\end{array}$} \\
\hline & & B & Std. Error & & & & \\
\hline \multirow[t]{8}{*}{1} & (Constant) & $-1,594$ & ,138 & & $-11,546$ &, 000 & \\
\hline & Tangible & ,326 & ,027 & ,302 & 12,081 & ,000 & ,724 \\
\hline & Reliability & ,252 & ,027 & ,207 & 9,184 & ,000 & ,576 \\
\hline & Responsiveness & , 154 & ,028 & , 145 & 5,566 & ,000 & ,620 \\
\hline & Assurance & ,039 & ,031 & ,032 & 1,262 & ,208 &, 549 \\
\hline & Empathy & ,143 & ,027 & ,123 & 5,355 & ,000 & ,528 \\
\hline & Atmosphere & ,266 & ,038 & , 186 & 6,930 & ,000 & ,688 \\
\hline & Food Quality & ,282 & ,030 & ,278 & 9,545 & ,000 & ,760 \\
\hline
\end{tabular}

a. Dependent Variable: Purchase Intention

2015) has proved that restaurant's atmosphere has a positive influence on consumers' purchase intention. According to the statements, it should be considered to create an interesting and comfortable atmosphere into a restaurant business in order to capture or retain more consumers as well as increasing their purchase intention.

H7: Atmosphere has a positive influence on purchase intention.

\section{RESEARCH METHODS}

Purchase intention was measured by 4 items of questionnaires in line with Hussain and Ali (2015). The service quality was designed by 22 items of questionnaires based on Parasuramanetal.(1988) with the dimensions of tangible, reliability, responsiveness, assurance, and empathy. In measuring food quality, it used a 5-item scale developed in accordance with Ryu, Lee, Kim, and Woo (2012) and Qin and Prybutok (2009). As for atmosphere, it was measured based on 8 items of the questionnaire in accordance with Hussain and Ali (2015).

This research was conducted based on a survey using questionnaires in order to learn the influence of service quality, food quality, and atmosphere on purchase intention. It took a sample of 384 respondents who have been to Chingu Café. The validity and reliability analysis was conducted by applying coefficient correlation where the coefficient of validity has to be greater than 0.3 and coefficient of reliability has to be greater than 0.6 . This research conducted a set of classic assumption test to learn the appropriateness from items of questionnaires to be analyzed. A multiple regression analysis was applied in order to learn the correlation of independent variables with the dependent variable.

Table 2. F Test

ANOVA ${ }^{b}$

\begin{tabular}{|c|c|c|c|c|c|c|}
\hline Model & & $\begin{array}{l}\text { Sum of } \\
\text { Squares }\end{array}$ & df & Mean Square & $\mathrm{F}$ & Sig. \\
\hline \multirow[t]{3}{*}{1} & Regression & 155,750 & 7 & 22,250 & 303,881 &, $000^{\mathrm{a}}$ \\
\hline & Residual & 27,531 & 376 & 073 & & \\
\hline & Total & 183,281 & 383 & & & \\
\hline
\end{tabular}

a. Predictors: (Constant), Food Quality, Reliability, Empathy, Assurance, Tangible,

Responsiveness, Atmosphere

b. Dependent Variable: Purchase Intention

\section{RESULTS AND DISCUSSION}

The majority of the respondents were female, comprising $77.9 \%$ of the total respondents or 299 in total. Respondents with the age range of $20-24$ years old are the most among the other age groups with 194 respondents or $50.5 \%$. Most of the respondents are university students with 221 respondents (57.6\%). The result is dominated by respondents from North Bandung with 147 respondents or $38.3 \%$ of the total respondents. This has able to learn unique findings in a Korean thematic café business. Based on the respondents, it is obtained that the most consumptive consumers are teenagers and young adults dominated by females. Most of them are students with lower spending, however, they are considered the potential in this business field. 
Table 3. Model summary of multiple liniear regression

\begin{tabular}{|l|r|r|r|r|}
\multicolumn{7}{c|}{ Model Summary } \\
\hline Model & R & R Square & $\begin{array}{c}\text { Adjusted } \\
\text { R Square }\end{array}$ & $\begin{array}{r}\text { Std. Error of } \\
\text { the Estimate }\end{array}$ \\
\hline 1 &, $922 \mathrm{a}$ &, 850 &, 847 &, 27059 \\
\hline
\end{tabular}

a. Predictors: (Constant), Food Quality, Reliability, Empathy, Assurance, Tangible, Responsiveness, Atmosphere

Based on table 3 , it is obtained that the regression coefficient $(R)$ is 0.922 . It indicates that there exists a strong relationship between tangible $(X 1)$, reliability $(X 2)$, responsiveness $(X 3)$, assurance $(X 4)$, empathy $(X 5)$, atmosphere (X6), and food quality (X7) with purchase intention $(\mathrm{Y})$.

Based on the $\mathrm{F}$ test analysis in Table 1, there exists a significant influence between all independent variables which are tangible (X1), reliability (X2), responsiveness $(X 3)$, assurance $(X 4)$, empathy $(X 5)$, atmosphere (X6), and food quality (X7) as a whole on the dependent variable which is purchase intention (Y) where $F$ count (303.881) is greater than $F$ table (2.034).

Table 4 shows the results of $t$ test analysis, it is obtained that most of the independent variables have a significant partial influence on purchase intention (Y) where each of the variable's t count is greater than $t$ table of 1.966. Tangible (X1) has the greatest influence where its t test is 12.081 and only assurance (X4) that does not have a significant partial influence on purchase intention $(\mathrm{Y})$ because its t count (1.262) is less than the t table (1.966).

Based on table 3, it is obtained a multiple regression formula as follows:

$Y=-1.594+0.326 X 1+0.252 X 2+0.154 X 3+0.039 X 4$ $+0.143 \times 5+0.266 \times 6+0.282 \times 7$

Based on the regression formula above, it is obtained that the constant value is -1.594 . It means that when all independent variables equal to zero, hence, the value of dependent variable s predicted to be -1.594 . The coefficient of variable's regression indicates a direction of the relationship of the variable which is related to purchase intention. Regression coefficient of variable $\mathrm{X} 1$ of 0.326 means that on every increase by one point of tangible (X1) increases purchase intention $(Y)$ of 0.326 , coefficient regression of variable $\mathrm{X} 2$ of 0.252 means that on every increase by one point of reliability (X2) increases purchase intention $(Y)$ as much as 0.252 , regression coefficient of variable X3 of 0.154 means that on every increase by one point coefficient of variable X 4 of 0.039 means of responsiveness (X3) increases purchase intention $(Y)$ as much as 0.154 , regression that on every increase by one point of assurance (X4) increases purchase intention $(Y)$ as much as 0.039 , regression coefficient of variable X5 of 0.143 means that on every increase by one point of empathy (X5) increases purchase intention $(Y)$ as much as 0.143 , regression coefficient of variable $\mathrm{X} 6$ of 0.266 means that on every increase by one point of atmosphere (X6) increases purchase intention $(Y)$ as much as 0.266 , regression coefficient of variable $\mathrm{X} 7$ of 0.282 means that on every increase by one point of food quality (X7) increases purchase intention $(\mathrm{Y})$ as much as 0.282 .

To summarize the findings, it is obtained that all dependent variables which are tangible (X1), reliability $(X 2)$, responsiveness $(X 3)$, assurance (X4), empathy (X5), atmosphere (X6), and food quality (X7) have a positive or unidirectional relationship with purchase intention. However, based on the significant level, only assurance dimension (X4) that does not have a significant influence on purchase intention $(\mathrm{Y})$ indicated by the sig. coefficient of 0.228 which exceeds 0.05. Hence, consumers' purchase intention is influenced by the variables studied where the regression coefficients indicated how great the variable affect purchase intention. Based on this research findings, the research problems or objectives may be answered through a practical implication where a business running in a Korean thematic section especially Korean thematic café may consider offering a greater level of its service quality, atmosphere, and food quality in order to increase consumers' purchase intention as well as to retain its consumers while offering a low level of service quality, atmosphere, and food quality may drive to consumers' decline or decrease in consumers' purchase intention. These findings are also supported based on the previous research where service quality, atmosphere, and food quality do have a positive relationship on purchase intention (Worek, Kindangen, \& Worang, 2015; Qin \& Prybutok 2009; Omotayo \& Joachim, 2008). However, this research obtained that assurance dimension of service quality does not have a significant influence on purchase intention. 


\section{JURNAL BISNIS \& MANAJEMEN}

ISSN 1412 - 3681

Besides considering on the level of service quality, atmosphere, and food quality, a business may create a marketing strategy based on the findings of respondent's profile. This research obtained that the most consumptive consumers at a Korean thematic café are university students and school students. This indicates that a Korean thematic business is able to attract more consumers with the age range of $15-24$ years old. It may be necessary to follow the trend in these consumers range of age to learn what is able to attract them the most.

Based on the results of this study concluded that there are ten attributes initial entered factor analysis, ultimately formed three new factors are in the process of naming a factor in this study is called (a) factors tariffs (tariffs) that consists of attributes tariff, (b) a service factor ( services) which consists of attributes on-time departure and arrival, safety, reservation and check-in convenience, airline crews, flight patterns, cabin services, baggage services, and airplanes, and (c) factors image of the airline (airline image) consisting of image airline attributes. These factors become consumer choice preference in using the services of airlines in Indonesia.

\section{CONCLUSION}

\section{Research conclusion}

This research has seven independent variables studied by a multiple linear regression analysis where seven independent variables are considered to be the maximum numbers to have an effective analysis (Santoso, 2016) which may create a wider findings or more complex results to study about consumers' purchase intention.

The strongest factor influencing purchase intention at Korean thematic café is a tangible dimension. It is followed by food quality, reliability dimension, atmosphere, responsiveness dimension, and empathy dimension. It is obtained that assurance dimension of service quality does not have a significant influence on purchase intention. Besides the variables which are being researched in this study, respondents would also pick food's taste, menu variation, and café's atmosphere over location and price in choosing a Korean thematic café.
In terms of Tangible dimension, customers once entered the restaurant might perceive themselves to reside in Korea. The Korean-designed style filled the ambiance of the restaurant from the waiting room that was decorated as the Korean Bus Stop, as well as music and video-clip playing the Korean-hits song, up to Korean sit-cross styles existed. The front door was made of glasses surrounded with the whitebricks wall. Paper-tree stood in the corner filled with the paper notes of experiences from the customers of being in the café. When the café was full, there was a waiting room decorated as the 'Korean Bus Stop' with a wall filled with posters of actor and actress murals. 'Gangnam Station' was one of the favorite places which emulated Korean Station along with the sign, direction, with tables and chairs mimicked the ambiance of Mass Rapid Transport. These were kinds of elements mostly valued by the customers on the uniqueness toward Korean Culture.

In terms of Food quality, the café had adapted to the requirement of Indonesian culture where Moslems are the majority of customers. All menu dishes were halal, and varied with a vast ranges of menu from Tteokbokki (spicy, slightly sweet and chewy rice cakes), Ramyun (spice-instant noodle), Hotteok (sweet pancakes), Jap Chae (sweet potato starch noodles stir fried with vegetables and meat), Bibimbap (mixed rice with meat and assorted vegetables), Chijeu Bokkeumbap (cheese fried rice), Pat Bingsoo (shaved ice dessert with sweet toppings), to Ring Bingsoo (marshmallow, popping boba, fruit loops, and vanilla ice cream). These variety of unique Korean menus were also highly valued by the customers.

In terms of Reliability dimension, the things that were the valued the most by the customers relate to the accurate billing and the affordable price to the targeted customer. The prices of these varieties of menus were not exceeding IDR 30.000, matching with the affordability of the college students as the main target customer.

In terms of Atmosphere dimension, the interior layout of furniture, and decorated walls was enchanted and fabulous. Besides that, cleanliness, and service appliances such as a brochure, menu book were also visually appealing to the customers. 
The tangible dimension of service quality that has a significant relationship with purchase intention approves hypothesis 1 . The other dimensions of service quality; reliability, responsiveness, and empathy also approve hypothesis 2, hypothesis 3, and hypothesis 5 in which reliability, responsiveness, and empathy dimension have a positive influence on purchase intention. But, assurance dimension does not have a positive influence on purchase intention which rejects hypothesis 4 .

The atmosphere as well as food quality have a positive influence on purchase intention to approve hypothesis 6 and hypothesis 7 . These findings are consistent with previous studies mentioned that the atmosphere and food quality do have a positive relationship with purchase intention (Worek, Kindangen, and Worang, 2015; Qin and Prybutok 2009; Omotayo and Joachim, 2008).

The findings of this research are unique, indicated by teenagers and young adults especially females mostly college students who were more keen to consume at this Korean thematic café rather than adults. It also means that the service quality dimensions as the elements of the marketing strategy of Chingu Café have been effective to attract the targeted college students to purchase supported by the appealing dimensions.

\section{Recommendation}

\section{Recommendation for Chingu Café}

Based on the findings of the analysis, it is recommended for Chingu Café to continue maintaining its service quality's dimensions which are tangible, reliability, responsiveness, and empathy as well as its atmosphere and food quality which have a positive or significant influence on consumers' purchase intention at a Korean thematic café. Chingu Café's owner may encourage the employees to serve consumers at their best as well as developing the devices or equipment used at the café. Chingu Café may explore its recipes and create new cuisines to widen the choice of the menu and to offer consumers a new taste of dining experience. Chingu Café may also create a better atmosphere by enlarging its space and giving new ornaments which are liked by consumers.
In particular, for the service quality, Chingu Café may install new technological devices or equipment to improve their effectiveness in serving consumers where can improve the quality of tangible dimension, reliability dimension, and responsiveness dimension which are considered to have a significant influence on purchase intention. Engaging a higher technology devices or equipment may help the virtual interface of consumers with the employees which enable the consumers to summon employees without seeking to look around in such a way that employees of Chingu Café can become more responsive in fulfilling consumers' calls. The café can expand its dining lots or re-arrange its place in order to be able to provide more dining tables and chairs for consumers as well as reducing the waiting list occurred at Chingu Café. Having a consumer care basis through social media or emails is suggested for Chingu Café to be performed to gain consumers heart by giving more attention or information as well as promotion related to the business which may drive to perform a higher quality of empathy dimension.

For the atmosphere of Chingu Café, the owner may be able to place new decorations or re-decor the café periodically and a specific decoration following the trend happens or specific celebration. It can help Chingu Café in providing a new atmosphere for consumers. Chingu Café can also widen its music choices and enable consumers to request what music to be played. Additional air conditioners may also be installed to improve the air quality in the dining rooms. An expert of interior and the exterior designer may also be hired in order to give insights in creating a better level of atmosphere in the café to increase the interest of consumers as well to increase their purchase intention.

As for food quality, Chingu Café may improve its ingredients quality to satisfy its consumers by adapting to the Indonesian taste. This required Chingu Café to offer more tempting smell of cuisines, flavor, nutrition, and fresher cuisines to satisfy consumers. Chingu Café is required to learn new recipés by observing the trend of Korean food adored among potential consumers which are teenagers and young adults. The chef of Chingu Café might follow a cooking course from a Korean chef or Korean cuisines to learn of creating a more original and tastier dishes while 
JURNAL BISNIS \& MANAJEMEN

ISSN 1412 - 3681

at the same time learning the adequate adaptation to Indonesian dishes. All in all, the aforementioned recommendation may help the café to increase and retain its customers as well as increasing their purchase intention appealed by new variations of menus while preventing them from being stuck with monotonous menu.

\section{Recommendation for next research}

This research focuses on studying the factors influencing consumers' purchase intention at Korean thematic café which are service quality, atmosphere, and food quality. It chose one object of study which is Chingu Café that only able to gather respondents from Bandung and Jakarta. As for the recommendation for the next research, it may able to gather wider respondents not only from Bandung and Jakarta but respondents outside both region as well by having a general object of study that may help to obtain respondents from other regions to generate wider results of the research. Another variable such as price consciousness and may able to be considered in developing the next research where it is still considered in the consumers' preference by the respondents in this research where some of them chose price in considering to make a purchase based on the questionnaire on the respondent profile section. A qualitative method or a mixed method of the quantitative method and qualitative method may also be conducted to generate a deeper and wider findings in the future research. In its contribution to academics, this research has learned that it is suggested for researchers to examine or observe the characteristics of respondents before distributing a questionnaire to them. It may help to create better question items which are more understandable by respondents in order to avoid bias.

\section{REFERENCES}

Cho, N \& Park, S (2001) "Development of electronic commerce user-consumer satisfaction index (ECUSI) for Internet shopping", Industrial Management \& Data Systems, Vol. 101 Issue: 8, pp.400-406, https://doi. org/10.1108/EUM0000000006170

Edvardsen, B., Tomasson, B. and Ovretveit , J. (1994). "Quality of Service: Making it Really Work",
Jurnal Bisnis \& Manajemen, 2017, Vol. XVIII, No. 2, 73-82

McGraw-Hill, New York.

Fandos, C. and Flavian, C.. (2006). "Intrinsic and Extrinsic Quality Attributes, Loyalty, and Buying Intention: An Analysis For a PDO Product", British Food Journal, 108(8), 646662.

Fitzsimmons, J. A., M. J. Fitzsimmons. (2008). "Service Management: Operations, Strategy, Information Technology", McGraw-Hill/ Irwin, New York.

Halim, W. Z. W and Hamed, A. B. (2005), "Consumer Purchase Intention at Traditional Restaurant and Fast Food Restaurant", University Utara Malaysia.

Hassan, H., Hashimi, M.S., and Sarwar, Z. (2014). "Exploring the Impact of retail Stores' Service Quality on Consumers' Purchase Intention: The Moderating Role of CSR", Middle-east Journalof ScientificResearch, 19(4), 505-520.

Hussain, R. and Ali, M. (2015). "Effect of Store Atmosphere on Consumer Purchase Intention". International Journal of Marketing Studies; Vol. 7, No. 2; 2015.

Omotayo, O. and Joachim, A. A. (2008). "Customer Service in the Retention of Mobile Phone Users in Nigeria", Academic Journal of Business Management, Vol.2 (2).

Parasuraman, A., Zeithaml, V. and Berry, L.L. (1988), "SERVQUAL: a multiple-item scale for measuring consumer perceptions of service quality", Journal of Retailing, Vol. 64, Spring, pp. 12-40.

Pérez, M.S, Abad, J.C.G, Carrillo, G.M.M, Fernández, R.S. (2007), "Effects of service quality dimensions on behavioural purchase intentions:Astudyin public-sectortransport", Managing Service Quality: An International Journal, Vol. 17 Issue: 2, pp.134-151, https:// doi.org/10.1108/09604520710735164

Pavlou, P. A. and Geven, D. (2004), "Building Effective 
Online Marketplaces with Institution-based Trust", Information System Research, 15, Informs, 37-59.

Pi, S., Liao, H., Liu, S., and Lee, I.. (2011), "Factors Influencing the Behavior of Online Group Buying in Taiwan", Journal of Business Management, 5(16), 7120-7129.

Qin, H., \& Prybutok, V. R. (2009). "Service Quality, Customer Satisfaction, and Behavioral Intentions in Fast-Food Restaurants", International Journal of Quality and Service Sciences, 1(1), 78-95.

Ryu, K., Lee, H. K., \& Woo, G. (2012). "The Influence of the Quality of the Physical Environment, Food, and Service on Restaurant Image, Customer Perceived Value, Customer Satisfaction, and Behavioral Intentions", International Journal of Contemporary Hospitality Management, 24(2), 200-223

Santoso, Singgih. (2016), "Panduan Lengkap SPSS Versi 23.", PT Elex Media Komputindo, Indonesia.
Shahin, Arash. (2006). "Servqual and Model of Service Quality Gaps: A Framework for Determining and Prioritizing Critical Factors in Delivering Quality Services", University of Isfahan.

Subhash C. Mehta, Ashok K. Lalwani, Soon Li Han, (2000). "Service quality in retailing: relative efficiency of alternative measurement scales for different product-service environments", International Journal of Retail \& Distribution Management, Vol. 28 Issue: 2, pp.62-72, https://doi. org/10.1108/09590550010315106

Wakefield, K. L. And Baker, J. (1998). “Excitement at the Mall: Determinants and Effects on Shopping Response", Journal of Retailing, Vol. 74(4), pp. 515-539.

Worek, Kindangen, and Worang. (2015). "The Effect of Restaurant Atmosphere and Service Quality on Customer Purchase Intention (Case Study of Danau Tondano Restaurant)".

Zeithaml, Bitner, and Gramler. (2006). "Services Marketing: Integrating Customer Focus across the Firm (4th ed., pp.117)", McGrawHill, Singapore. 